\title{
ANALISIS KEPEMIMPINAN, MOTIVASI DAN MASA KERJA TERHADAP KINERJA DINAS PERTANIAN DAN PETERNAKAN KABUPATEN PRINGSEWU
}

\author{
Riasmira $^{1)}$, Dhel Juni Pasya ${ }^{2)}$ \\ ${ }^{1}$ Fakultas Ekonomi dan Bisnis, Universitas Muhmmadiyah Pringsewu \\ ${ }^{2}$ Fakultas Ekonomi dan Bisnis, Universitas Muhmmadiyah Pringsewu \\ Email: dheljunifeb@umpri.ac.id \\ Email : riasmira14@gmail.com
}

\begin{abstract}
Abstrak
Penelitian ini bertujuan untuk mengetahui analisis kepemimpinan, motivasi kerja dan masa kerja terhadap kinerja pegawai pada dinas pertanian dan peternakan kabupaten Pringsewu. Uji hipotesis dilakukan dengan cara Uji Simultan, dilakukan untuk mengetahui ada tidaknya pengaruh secara bersama-sama antara variabel bebas terhadap variabel terikat dengan menggunakan Uji $\mathrm{F}$ pada taraf kepercayaan 95\% dengan derajat bebas $(\mathrm{dk} 1)=\mathrm{k}$ dan $(\mathrm{dk} 2)=\mathrm{n}-\mathrm{k}-1$. Populasi dari penelitian ini adalah pegawai pada dinas pertanian dan peternakan kabupaten pringsewu sebanyak 130 pegawai . Sampel dalam penelitian ini adalah 88 pegawai Berdasarkan hasil penelitian diketahui bahwa Ha diterima. Kepemimpinan, motivasi kerja dan masa kerja berpengaruh terhadap kinerja pegawai pada Dinas pertanian dan petenakan kabupaten Pringsewu, sehingga semua variabel pada kepemimpinan, motivasi dan masa kerja berpengaruh terhadap kinerja pegawai dinas pertanian dan peternakan kabupaten pringsewu secara signifikan.
\end{abstract}

Kata Kunci : Pemimpin, Motivasi, masa kerja dan Kinerja

\section{PENDAHULUAN}

Pada dasarnya setiap instansi yang didirikan mempunyai harapan bahwa kelak di kemudian hari akan mengalami perkembangan yang pesat di dalam lingkup kegiatannya dan menginginkan terciptanya produktivitas yang tinggi dalam bidang pekerjaannya. Untuk mewujudkan operasinya tersebut dibutuhkan beberapa faktor produksi yaitu, tenaga kerja, modal, dan keahlian, dimana keempat faktor tersebut tidak dapat berdiri sendiri, melainkan harus saling mendukung untuk mencapai tujuan secara efektif dan efisisen dan diantara keempat faktor utama tersebut faktor tenaga kerja atau manusia dalam hal ini adalah pegawai, merupakan hal yang 
terpenting karena manusia merupakan pemakai dan penggerak serta penentu dari semua aktivitas.

Setiap instansi pemerintah dituntut untuk dapat mengoptimalkan sumber daya manusia dan bagaimana sumber daya manusia dikelola. Pengelolaan sumber daya manusia tidak lepas dari faktor pegawai yang diharapkan dapat berprestasi sebaik mungkin demi mencapai tujuan instansi pemerintah. Pegawai suatu instansi merupakan aset utama instansi tersebut dan mempunyai peran yang strategis di dalam struktur organisasi instansi pemerintah yaitu sebagai pemikir, perencana, dan pengendali aktivitas dalam instansi. Untuk menciptakan kinerja yang tinggi, dibutuhkan adanya peningkatan kerja yang optimal dan mampu mendayagunakan potensi Sumber Daya Manusia. Robbin (2006) menyatakan bahwa kepemimpinan merupakan kemampuan untuk mempengaruhi kelompok menuju pencapaian sasaran.

\section{METODE PENELITIAN}

Variabel penelitian adalah hal-hal yang dapat membedakan atau membawa variasi pada nilai (Sekaran, 2006). Penelitian ini menguji dua variabel yaitu variabel independen dan varibel dependen. Variabel independen dalam penelitian ini adalah adalah kepemimpinan, motivasi kerja dan masa kerja, sedangkan variabel dependen adalah kinerja pegawai, penelitian dilaksanakan pada dinas pertanian dan petrnakan Kabupaten Pringsewu, pada tahun 2019. Subjek pada penelitian ini adalah pegawai Dinas peternakan dan pertanian Kabupaten Pringsewu, tehknik pengumpulan data menggunakan studi kepustakaan, studi lapangan meliputi wawancara, observasi, koesoner dan dokumnetasi.

Populasi adalah keseluruhan subjek penelitian (Arikunto, 2003). Populasi dalam penelitian ini adalah seluruh pegawai Dinas Pertanian dan Peternakan Kabupaten Pringsewu yang berjumlah 113 orang pegawai. Sedangkan Sampel adalah sebagian dari populasi yang karakteristiknya hendak diselidiki dan dianggap bisa mewakili keseluruhan populasi (Arikunto, 2003). Penentuan sampel harus memperhatikan sifat-sifat dan penyebaran populasi agar diperoleh sampel yang representatif atau benar-benar mewakili populasi. 
Untuk menentukan ukuran sampel dari populasi digunakan rumus Slovin (Arikunto, 2003), sebagai berikut:

$$
\mathrm{n}=\frac{\mathrm{N}}{1+\mathrm{N}\left(\mathrm{d}^{2}\right)}
$$

Dimana :

$$
\begin{array}{ll}
\mathrm{n} & =\text { ukuran sampel } \\
\mathrm{N} & =\text { ukuran populasi } \\
\mathrm{D} & =\text { persen kelonggaran karena kesalahan pengambilan sampel yang } \\
& \text { masih ditolelir atau diinginkan }
\end{array}
$$

Berdasarkan rumus Slovin untuk jumlah populasi 113 orang, maka jumlah sampel yang akan diteliti dengan batas kesalahan yang diinginkan 0,05 , adalah:

$$
\begin{aligned}
\mathrm{n} & =\frac{113}{1+113(0.05)^{2}} \\
& =\mathbf{8 8 \text { orang }}
\end{aligned}
$$

Jadi sampel dalam penelitian ini berjumlah 88 orang.

\section{HASIL DAN PEMBAHASAN}

Data hasil pengolahan kuesioner yang telah disebarkan kepada responden pada pegawai Dinas Pertanian dan Peternakan Kabupaten Pringsewu sebanyak 88 (empat puluh enam) responden dengan pernyataan-pernyataan yang berkaitan tentang kinerja, kepemimpinan, motivasi kerja, serta masa kerja. Berikut gambaran Deskripsi dari 88 responden pegawai Dinas Pertanian dan Peternakan Kabupaten Pringsewu sebagaimana diperjelas dalam tabel sebagai berikut:

\section{Tabel 1. Deskripsi Responden tentang Jenis Kelamin}

\begin{tabular}{lcc}
\hline \multicolumn{1}{c}{ Jenis Kelamin } & Jumlah & \% \\
\hline Perempuan & 29 & 36,95 \\
Laki-laki & 59 & 67,05 \\
\hline Total & 88 & 100 \\
\hline
\end{tabular}


Berdasarkan tabel 1, sebagian besar pegawai Dinas Pertanian dan Peternakan Kabupaten Pringsewu berjenis kelamin laki-laki 67,05\%, sedangkan perempuan sebesar 36,95\%. Hasil tersebut menunjukkan bahwa laki-laki lebih dominan disebabkan karena laki-laki bersedia bekerja dengan tantangan dalam waktu kapan saja.

Tabel 2. Deskripsi Responden tentang Umur Responden

\begin{tabular}{lcc}
\hline \multicolumn{1}{c}{ Interval Umur } & Jumlah & \% \\
\hline 20-30 Tahun & 16 & 18,18 \\
31-40 Tahun & 52 & 59,09 \\
41-50 Tahun & 20 & 22,73 \\
\hline Total & 88 & 100 \\
\hline
\end{tabular}

Berdasarkan Tabel 2 sebagian besar pegawai pada Dinas Pertanian dan Peternakan Kabupaten Pringsewu untuk usia sangat produktif 20 -30 sebesar 18,18\%, sedangkan usia Produktif 31-40 sebesar 59,09\%, serta usia agak Produktif 41-50 sebesar 22,73\%, dimana hasil tersebut menunjukkan bahwa diperlukan pegawai usia sangat produktif, disebabkan pekerjaan yang dilakukan membutuhkan tenaga yang lebih aktif.

Tabel 3. Deskripsi Responden tentang Pendidikan Responden

\begin{tabular}{lcc}
\hline \multicolumn{1}{c}{ Jenjang Pendidikan } & Jumlah & \% \\
\hline SMP & 2 & 2,27 \\
SMA & 9 & 10,23 \\
D3 & 20 & 22,73 \\
S1 & 48 & 54,55 \\
S2 & 9 & 10,23 \\
\hline Total & 88 & 100 \\
\hline \multicolumn{2}{c}{ Berdasarkan tabel 3, sebagian besar pegawai pada Dinas Pertanian dan }
\end{tabular}

Peternakan Kabupaten Pringsewu adalah mencapai jenjang Pendidikan S2 sebesar 10,23\%, S1 sebesar 54,55\%. D3 sebesar 22,73\%. SMA sebesar 10,23\% dan SMP sebesar $2,27 \%$. Hasil tersebut menunjukkan rata-rata jenjang pendidikan pegawai termasuk tinggi disebabkan pegawai memerlukan standar pengetahuan yang lebih selain tentang pekerjaan. 
Tabel 4. Deskripsi Responden tentang Masa kerja Responden

\begin{tabular}{lll}
\hline Masa kerja & Jumlah & $\%$ \\
\hline 0-10 Tahun & 43 & 48,86 \\
11-20 Tahun & 39 & 44,32 \\
21-30 Tahun & 6 & 6,82 \\
\hline Total & 88 & 100 \\
\hline
\end{tabular}

Berdasarkan tabel 4, sebagian besar pegawai pada Dinas Pertanian dan Peternakan Kabupaten Pringsewu memiliki masa kerja selama 0-10 Tahun sebesar 48,86\%, 11-20 Tahun sebesar 44,32\%, 21-30 Tahun sebesar 6,82\%,. Hasil tersebut menunjukkan bahwa sebagian besar pegawai termasuk mempunyai pengalaman kerja yang cukup. Sedangkan tanggapan masing-masing responden mengenai Deskripsi variabel kinerja, kepemimpinan, motivasi, dan masa kerja Pegawai pada Dinas Pertanian dan Peternakan Kabupaten Pringsewu, berdasarkan indikatornya lebih jelas pada analisis kualitatif.

Untuk mengetahui pengaruh ketiga variabel bebas yaitu kepemimpinan , motivasi kerja dan masa kerja terhadap variabel terikat kinerja pegawai menggunakan bantuan program SPSS dengan hasil sebagai berikut :

Tabel 5 Model Summary

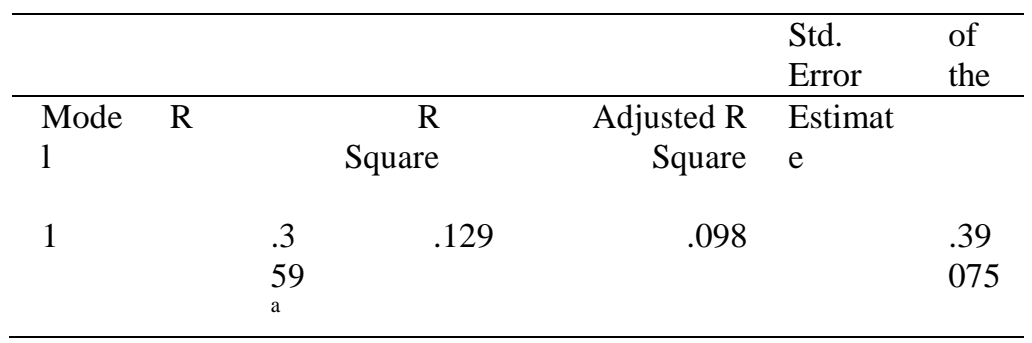

Berdasarkan Tabel 5 dapat dilihat bahwa secara bersama-sama variabel Kepemimpinan, Motivasi kerja dan Masa Kerja memiliki hubungan yang lemah dan positif dengan Kinerja Pegawai di Dinas Pertanian dan Peternakan Kabupaten Pringsewu $\left(r X_{1} X_{2} X_{3} Y=0,359\right)$. 
Dari Tabel 5 juga dapat disimpulkan nilai $R$ squere sebesar 0,129 yang berarti secara bersama-sama variabel bebas Kepemimpinan, Motivasi kerja dan Masa Kerja memberikan kontribusi pengaruh terhadap tinggi rendahnya (variasi nilai) Variabel Kinerja Pegawai di Dinas Pertanian dan Peternakan Kabupaten Pringsewu sebesar 12,9\%, sedangkan kontribusi diluar variabel sebesar $87,1 \%$ Kinerja Pegawai disebabkan variabel-variabel lain yang tidak dimasukkan kedalam model. Pengaruh kepemimpinan, motivasi kerja, masa kerja terhadap kinerja Pegawai.

Berdasarkan hasil penelitian didapatkan Uji $F$ digunakan untuk mengetahui apakah kepemimpinan, Motivasi kerja dan Masa kerja secara bersama-sama berpengaruh terhadap kinerja pegawai. Berdasarkan hasil perhitungan diperoleh signifikansinya adalah $\mathrm{P}(\mathrm{Sig}) 0,009<0,05$ yang berarti Ho ditolak dan menerima Ha sehingga dengan demikian hipotesis dapat dinyatakan “Ada pengaruh Kepemimpinan, Motivasi kerja dan Masa Kerja secara bersamasama terhadap Kinerja Pegawai di Dinas Pertanian Dan Peternakan Kabupaten Pringsewu" dapat diterima kebenarannya. Secara bersama-sama variabel Kepemimpinan, Motivasi kerja dan Masa Kerja memiliki hubungan yang lemah dan positif dengan Kinerja Pegawai Negeri $\left(\mathrm{rX}_{1} \mathrm{X}_{2} \mathrm{X}_{3} \mathrm{Y}=0,359\right)$.

Nilai $R$ squere sebesar 0,129 yang berarti secara bersama-sama variabel bebas Kepemimpinan $\left(\mathrm{X}_{1}\right)$, Motivasi kerja $\left(\mathrm{X}_{2}\right)$ dan Masa Kerja $\left(\mathrm{X}_{3}\right)$ memberikan kontribusi pengaruh terhadap (variasi nilai) Variabel Kinerja Pegawai (Y) di Dinas Pertanian dan Peternakan Kabupaten Pringsewu sebesar 12,9\%, sedangkan sebesar $87,1 \%$ Kinerja Pegawai disebabkan variabel-variabel lain yang tidak dimasukkan kedalam model. 
ISSN Cetak : 2087-0434

E-ISSN $\quad: 2599-0810$

\section{KESIMPULAN}

Berdasarkan hasil analisa dan pembahasan maka dapat disimpulkan, ada pengaruh positif dan signifikan kepemimpinan terhadap Kinerja Pegawai, begitu juga dengan motivasi ada pengaruh secara signifikan. Sedangkan masa kerja tidak memiliki pengaruh terhadap kinerja di Dinas Pertanian dan Peternakan Kabupaten Pringsewu. Hal ini dapat diartikan apabila pemerintah Kabupaten Pringsewu berkeinginan meningkatkan Kinerja Pegawainya, maka salah satu yang dapat ditempuh adalah dengan meningkatkan pelaksanaan Kepemimpinan yang baik. Kepemimpinan, Motivasi kerja dan Masa kerja secara bersama-sama berpengaruh positif tetapi dan signifikan terhadap Kinerja Pegawai di Dinas Pertanian dan Peternakan Kabupaten Pringsewu, dan ketiga variabel tersebut berkontribusi 12,9\% dalam mempengaruhi Kinerja Pegawai di Dinas Pertanian Dan Peternakan Kabupaten Pringsewu, sedangkan 87,1\% Kinerja Pegawai dipengaruhi variabel lain yang tidak dimasukkan kedalam model.

\section{DAFTAR REFERENSI}

Anasthasia, S. 2007. Influence Of Ability and Motivation to Government. http://www.fisip.undip.ac.id/in/index.php?par=skripsiview\&pidskripsi=19.

Arikunto, Suharsimi. 2003. Prosedur Penelitian, Suatu Pendekatan Praktek. Cetakan Kesebelas Edisi Revisi IV. PT. Rineka Cipta Jakarta.

Bass, Bernard M and Avolio, Bruce J, 1993, "Tansformational Leadership And Organizational Culture," Public Administration Quarterly, 17:1, 112-121.

Cokroaminoto, 2007, "Membangun Kinerja (Memaknai Kinerja Karyawan)," Google/15012008/cokroaminoto.wordpress.com/20070523/memaknaikine rjakaryawan.

Fuad Mas'ud, 2004, "Survai Diagnosis Organisasional," Badan Penerbit Universitas Diponegoro, Semarang.

Gibson, James L et al 2006, "Organizations (Behavior, Structure, Processes)," Twelfth Edition, McGrow Hill. 
Ghozali, Imam, 2008, “Konsep dan Aplikasi Dengan Program AMOS 16.0”, BP Undip, Semarang

Kreitner, Robert; dan Kinicki, Angelo, 2005,"Perilaku Organisasi”, Buku 1, Edisi Kelima, Salemba Empat, Jakarta.

Luthans, Fred, 2006, "Perilaku Organisasi", Edisi Sepuluh, Penerbit Andi,_Yogyakarta

Mangkunegara, Anwar Prabu. 2001. Manajemen Sumber Daya Manusia Perusahaan. PT. Remaja Rosdakarya. Bandung. 172 p.

Miftah Thoha, 1983, "Perilaku Organisasi; Konsep Dasar dan Aplikasinya”, Edisi 1, PT RajaGrafindo Persada, Jakarta.

Peraturan Bupati Lampung Utara Nomor 10 Tahun 2009 tanggal 20 Agustus 2009 tentang Tugas Pokok Instansi Pemerintah Daerah Kabupaten Lampung Utara.

Robbins, Stephen P, 2006, “Perilaku Organisasi, Edisi kesepuluh, PT Indeks Jakarta.

Schein, Edgar H, 2004, Organizational Culture and Leadership, Third Edition, Jossey -Bass Publishers, San Francisco.

Siagian, Sondang P, 2002, "Kiat Meningatkan Produktivitas Kerja”, PT. RINEKA CIPTA, Jakarta.

Silalahi, B. 2001. Penilaian Unjuk Kerja. Manajemen Interaktif.

Simamora, Henry, 1997. Manajemen Sumber Daya Manusia. Edisi kedua. STIE.

Suharto dan Budi Cahyono. 2005, Pengaruh Budaya Organisasi, Kepemimpinan dan Motivasi Kerja Terhadap Kinerja Sumber Daya Manusia, di sekretariat DPRD Propinsi Jawa Tengah, JRBI. Vol. 1, No.1, januari 2005: 13-30.

Veithzal Rivai, 2004, Kepemimpinan dan Perilaku Organisasi, Edisi Kedua PT Rajagrafindo Persada, Jakarta.

Yukl, Gary, 2005, Kepemimpinan Dalam Organisasi, Edisi kelima, PT Indeks, Jakarta. 